SHS Web of Conferences 10, 00022 (2014)

DOI: $10.1051 /$ shsconf/20141000022

C Owned by the authors, published by EDP Sciences, 2014

\title{
Comparative analysis of subjective well-being of Latvia's inhabitants in the context of economic development of European countries
}

\author{
J. Lonska \\ Daugavpils University, Latvia
}

\begin{abstract}
In the world, during the past 10 years, when evaluating development of a particular area, there has been a tendency of taking into consideration subjective evaluation and attitude to the living conditions of inhabitants living in this area. More often these indicators are the general life satisfaction and feeling of happiness. Analysing Latvia's place in these ratings, it is possible to conclude that inhabitants of Latvia are very pessimistic in assessing their lives in this country. As surveys indicate, the economic factors have an important influence on people's subjective satisfaction. The problem of the research is that during the last two years, there has been a tendency to improvement of the economic indicators in all three Baltic States, but when comparing the closest neighbours, the Latvian inhabitants' subjective satisfaction with life is decreasing, but in Lithuania and Estonia it is increasing together with improvement of the economic situation. In this article the author suggests her own vision of the situation in relation to the arrangement of countries according to subjective indicators analysing the influence of objective socio-economic factors on subjective opinions about living conditions of the inhabitants living in Latvia and neighbouring countries.
\end{abstract}

\section{Introduction}

In the second half of the $20^{\text {th }}$ century, research of life quality and subjective well-being became more urgent and important. Thereafter in the world, when evaluating development of a particular area, there has been a tendency to take also into consideration inhabitants' subjective evaluation and attitude to the living conditions that live in this area. Consequently, quite a few ratings, surveys and reports were worked out by just arranging countries according to their inhabitants' subjective evaluation and views; more often these indicators are the general satisfaction with life and feeling of happiness.

Analysing various factors influencing inhabitants' subjective well-being, researchers note the economic factor as the first and the most important one, i.e. economic situation in the country, people's material resources and income, which create and influence person's economic well-being as a whole.

When reviewing Latvia's place in ratings in relation to subjective well-being, one may note that its inhabitants' subjective perception of life in the country is very pessimistic even if we compare the situation with the closest neighbouring countries - Lithuania and Estonia. In the present article, the author will consider and evaluate the influence of the economic factors on people's subjective well-being

This is an Open Access article distributed under the terms of the Creative Commons Attribution License 4.0, which permits unrestricted use, distribution, and reproduction in any medium, provided the original work is properly cited. 


\section{SHS Web of Conferences}

Table 1. Comparison of Latvia, Lithuania and Estonia's current ranking according to the Eurobarometer evaluation according to the situation five years ago (Eurobarometer 2011).

\begin{tabular}{|l|l|l|l|}
\hline \multirow{2}{*}{ Country } & \multicolumn{2}{|l|}{ "Your life in general?" } & \multirow{2}{*}{$\begin{array}{l}\text { Better/worse } \\
\text { index 2011/2006 }\end{array}$} \\
\cline { 2 - 4 } & 2011 & Compared with 2010 & \\
\hline Latvia & 0.6 & -0.2 & -35 \\
\hline Lithuania & 0.4 & -0.1 & -39 \\
\hline Estonia & 2.3 & +0.4 & +4 \\
\hline EU27 & 3.5 & +0.4 & -2 \\
\hline
\end{tabular}

in the context of three Baltic States and the closest Nordic countries, the author will also substantiate the application of subjective indicators in evaluating the territorial development.

The problem of the research is that during 2010-2011, there has been growth of the gross domestic product (GDP) per capita in Latvia and in the closest neighbouring countries, i.e. in Lithuania and Estonia, but when comparing indicators of the subjective satisfaction with life in these countries, it was noted that Latvian inhabitants' subjective satisfaction with life is decreasing, but in Lithuania and Estonia it is increasing together with the improvement in the economic situation.

The aim of the research is to consider theoretical studies about the relation of people's subjective well-being to economic and material conditions, as well as to analyse them referring to Latvia.

\section{Materials and methods}

In this article the following research methods were applied: the monographic method applied in literature review, secondary analysis of data of previous studies and statistics to illustrate the research problem as well as to prove the hypotheses. The author's research was based on the scientific works of Western economists (on the topic of subjective well-being of people and economic development of states), on the empirical data of Eurobarometer's studies, as well as on statistical data of Eurostat.

The author solves the following tasks: summarising the theoretical research of the world researchers and scientists on the topic of the impact of the economic factor on people's subjective well-being, examination of Latvia's ranking in the world ratings and accounts on subjective well-being and its comparison with the closest Baltic Sea region countries, analysis of the most important economic indicators, making conclusions.

In the research, the following hypotheses have been put forward:

H1 - subjective well-being of Latvian inhabitants depends not only on the GDP per capita level, but also on such state macroeconomic indicators as the rate of unemployment and income inequality.

H2 - subjective well-being of Latvian inhabitants depends on people's economic conditions: financial assets and debts.

\section{Results}

Evaluation analysis of subjective well-being of Latvian inhabitants

Analysing Latvia's place in various ratings, which take into account subjective indicators, it is possible to conclude that inhabitants of Latvia are very pessimistic in evaluating their life in the country.

Analysing the three Baltic States' inhabitants' answers to the Eurobarometer question "Your life in general?" in 2011, Latvians evaluate subjectively their life conditions with 0.6 points (if " -10 " is the lowest assessment, " $+10 "$ is the highest assessment), and if comparing with 2010 , this assessment reduced by -0.2 points; in Lithuania this reduction made -0.1 point, reaching 0.4 point in 2011 , but in Estonia there has even been a slight growth by +0.4 point, reaching the overall assessment of 
Int. Conf. SOCIETY. HEALTH. WELFARE.
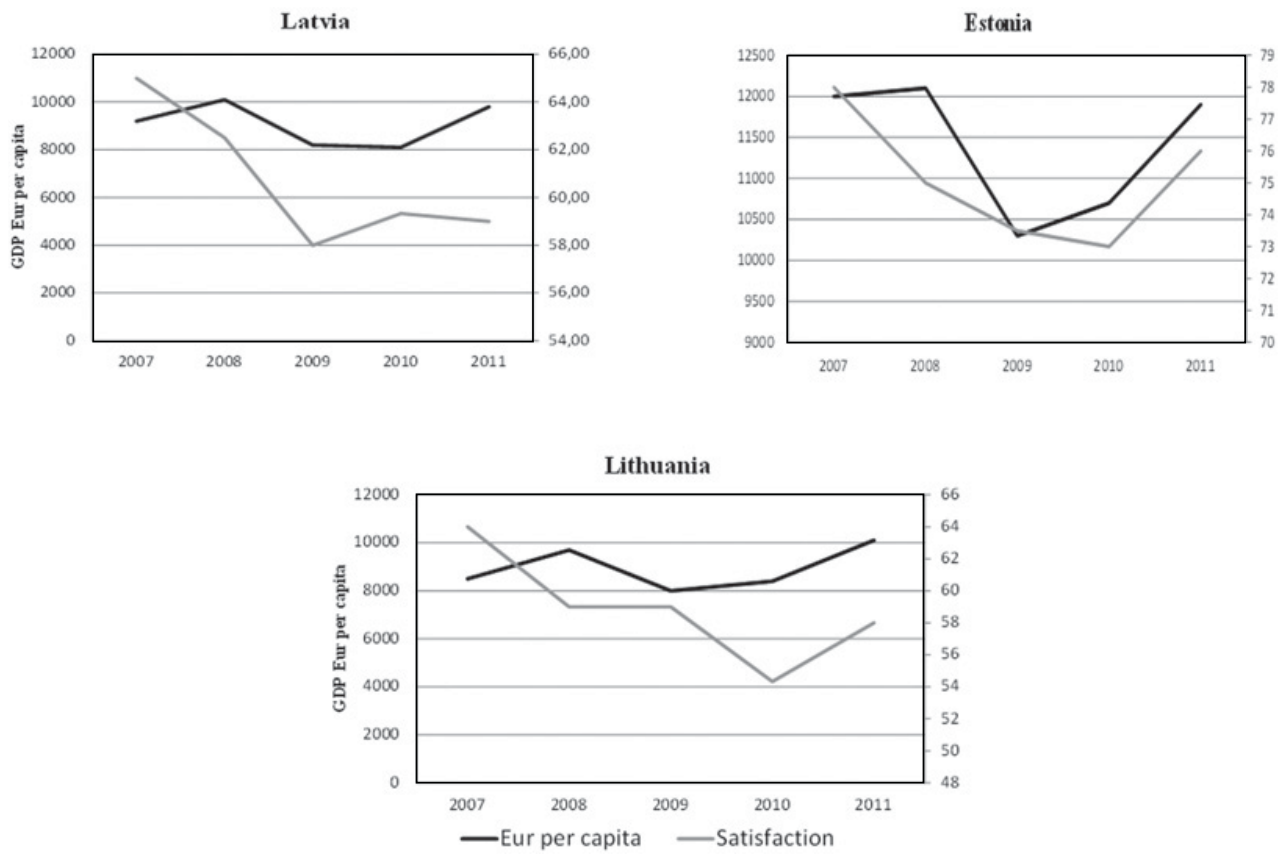

Figure 1. Trends in GDP per capita and life satisfaction (satisfied inhabitants \% from total inhabitants), Latvia, Estonia and Lithuania in 2007-2011 (compiled by the author using the Eurobarometer 2007a,b, 2008a,b, 2009a,b, 2010a,b, 2011).

2.3 points (see Table 1). Reviewing the Eurobarometer's better/worse index ${ }^{1}$ results in 2011, providing information about people's subjective evaluation of current life conditions in comparison with conditions five years ago, we can see that Latvian inhabitants' opinion is negative and reaches -35 points on the scale from -100 (the lowest) to +100 (the highest), the opinion of Lithuanian inhabitants is even lower ( -39 points), but Estonian inhabitants evaluate current life conditions in a more positive way than it was five years ago ( +4 points) (see Table 1$)$.

Reviewing the ranking of world's countries in 2010 according to the indicator of the Human Development Report "Overall life satisfaction", the three Baltic States also have the lowest assessment (4.7 points, if " 0 " - the least satisfied, " 10 " - the most satisfied), but Lithuanian and Estonian inhabitants' evaluation is at the same level -5.1 points (Human Development Report 2011).

Countries' ranking according to the Legatum Prosperity Index 2011 indicator "Average life satisfaction" is as follows: Latvia is on the $86^{\text {th }}$ place amongst 110 countries of the world, Lithuania ranks as the $72^{\text {nd }}$, but Estonia ranks as the $68^{\text {th }}$ (Legatum Prosperity Index 2011).

Analysis of economic indicators of Latvia and closest neighbouring Baltic Sea Region countries

Rating data of the World Database of Happiness of the time period 2001-2010, the level of Average Happiness of Latvian inhabitants is assessed with 5.3 points (where "0" is the lowest and "10" is the highest), the level of happiness of inhabitants in the neighbouring Lithuania is 5.5, but the northern neighbours of Latvia - Estonians - assess their happiness with 6.0 points according to the 10-point scale. (Veenhoven 2011).

\footnotetext{
${ }^{1}$ The better-worse index was created by calculating the difference in percentage points between the two extreme answer categories of question "Compared with five years ago, would you say things have improved, gotten worse or stayed about the same when it comes to your life in general?" ("better" - "worse"). This brings to an index on a scale from -100 to +100 . The neutral answer categories and the "don't know" responses were not taken into account when calculating this index.
} 


\section{SHS Web of Conferences}

Table 2. Values of GDP per capita, growth of GDP, inflation, unemployment and income inequality indicators in 2011 in Latvia, Lithuania and Estonia and the average in EU27, (compiled by the author using the Eurostat data).

\begin{tabular}{|l|l|l|l|l|l|}
\hline 2011 & $\begin{array}{l}\text { GDP per capita } \\
\text { at market prices } \\
(\text { EUR) }\end{array}$ & $\begin{array}{l}\text { Real GDP growth } \\
\text { rate (change in } \\
\text { previous year (\%) }\end{array}$ & $\begin{array}{l}\text { Inflation (annual } \\
\text { average rate of } \\
\text { change (\%) }\end{array}$ & $\begin{array}{l}\text { Unemployment } \\
\text { rate (\%) }\end{array}$ & $\begin{array}{l}\text { Income } \\
\text { Inequality } \\
\text { (Gini } \\
\text { coefficient) }\end{array}$ \\
\hline Latvia & $\mathbf{9 8 0 0}$ & 5.5 & 4.2 & $\mathbf{1 6 . 3}$ & $\mathbf{3 5 . 2}$ \\
\hline Lithuania & 10200 & 5.9 & 4.1 & 15.4 & 32.9 \\
\hline Estonia & 11900 & 8.3 & $\mathbf{5 . 1}$ & 12.5 & 31.9 \\
\hline Germany & 31700 & 3.0 & 2.5 & 5.9 & 29.0 \\
\hline Sweden & 41100 & 3.9 & 1.4 & 7.5 & 24.4 \\
\hline Denmark & 43000 & $\mathbf{1 . 1}$ & 2.7 & 7.6 & 27.8 \\
\hline Finland & 35200 & 2.7 & 3.3 & 7.8 & 25.8 \\
\hline EU27 & 25200 & 1.5 & 3.1 & 9.7 & $30.5 *$ \\
\hline
\end{tabular}

*In 2010.

Analysing changes of GDP per capita of the three Baltic States and changes in their inhabitants' subjective satisfaction with life from 2007 to 2011, it is possible to see that in cases with Estonia and Lithuania the inhabitants' satisfaction directly correlates to GDP changes within the entire period. In its turn, in Latvia it is not as simple - starting from 2010 there has been a tendency of GDP growth, but it has not positively influenced the indicator of the inhabitants' subjective life satisfaction - it is still decreasing (see Fig. 1).

We may ground the absence of growth of the indicator of Latvian inhabitants' subjective wellbeing along with the growth of the level of GDP per capita by additional influence of other economic factors (see Table 2), which will be considered below and with the influence of other non-economic determinants of subjective well-being.

Analysing data in Table 2 it is possible to see that in the situation with Latvia there is the largest number of the lowest indicator values (and the highest one for the unemployment rate and the Gini index) amongst close neighbouring countries of the Baltic Sea Region (these values are written in bold fonts) - in total three values: the lowest GDP amount per capita, the highest rate of unemployment and the highest Gini coefficient. Estonia has one value, i.e. the highest inflation rate, and Denmark also has one value, i.e. the lowest GDP growth rate. The level of inflation in Estonia can be explained by the introduction of euro currency at the beginning of 2011, though officially it was explained that it became the reason for $0.2-0.3 \%$ growth of inflation only (Rimgailaite 2012). But as concerns the speed of growth of GDP in Denmark, at the moment GDP per capita is one of the highest both in Europe and in the world, therefore the author believes that lowering the rate of GDP growth is not strongly influencing Denmark's inhabitants' subjective satisfaction.

Analysing the three Baltic States' and the closest neighbouring countries' gross and net financial assets per capita in 2011, one may conclude that Latvia is at the end of the list once again (see Table 3 ).

Looking at the data in the table, it becomes evident that inhabitants of Latvia are the poorest among the inhabitants of the mentioned above countries, Latvian's average net financial assets (money, securities, bank deposits, other investments, insurance policies, i.e. all people's financial property, without his/her obligations) make only 1392 EUR, i.e. almost 3 times less that Lithuanian's average net financial assets and 7 times less, if we compare the data with the Estonian's net financial assets. Furthermore Estonia belongs to the group of middle-wealth countries, but Latvia and Lithuania are still 
Int. Conf. SOCIETY. HEALTH. WELFARE.

Table 3. Inhabitants' gross and net financial assets, GDP per capita in 2011 in euro, (compiled by the author on the basis of the Allianz Global Wealth Report 2012 and Eurostat data).

\begin{tabular}{|l|l|l|l|l|}
\hline 2011 year & $\begin{array}{l}\text { (1) Gross financial } \\
\text { assets } \\
\text { (EUR per capita) }\end{array}$ & $\begin{array}{l}\text { (2) Net financial } \\
\text { assets } \\
\text { (EUR per capita) }\end{array}$ & $\begin{array}{l}\text { (1): (2) } \\
\text { Debt burden }\end{array}$ & $\begin{array}{l}\text { GDP per capita } \\
\text { at market prices } \\
\text { (EUR) }\end{array}$ \\
\hline Latvia (LWC)* & $\mathbf{5 2 9 0}$ & $\mathbf{1 3 9 2}$ & $\mathbf{3 . 8}$ & $\mathbf{9 8 0 0}$ \\
\hline Lithuania (LWC) & 7349 & 4089 & 1.8 & 10200 \\
\hline Estonia (MWC)** & 15540 & 9672 & 1.6 & 11900 \\
\hline Germany (HWC) & 57384 & 38521 & 1.5 & 31700 \\
\hline Sweden (HWC)*** & 77962 & 42104 & 1.9 & 41100 \\
\hline Denmark (HWC) & 113463 & 49220 & 2.3 & 43000 \\
\hline Finland (MWC) & 43042 & 19105 & 2.3 & 35200 \\
\hline World & 21493 & 14881 & 1.4 & - \\
\hline
\end{tabular}

* Low wealth country, $* *$ middle wealth country, $* * *$ high wealth country.

in the group of low wealth countries (according to the gross and net financial asset sum per capita). Gross financial assets (i.e. net financial assets and all obligations and debts) are also the smallest in Latvia in comparison with the above-mentioned countries, but the relation between gross and net financial assets, so-called debt burden is one of the highest, reaching 3.8.

\section{Discussion}

So far, the question "Is money the secret of happiness?", or like researchers say, "Will raising the income of all increase the happiness of all?" has been left open: scientists and researchers from all over the world are getting completely different results when trying to find an answer to the aforesaid question.

The most frequently analysed indicator is country's GDP rate impact on people's subjective wellbeing. Carrying out their studies, some scientists come to conclusions that (1) there is no significant connection between the country's GDP and people's subjective well-being, or the observed connection is weak (Easterlin 1974, 1995; Rojas 2011), (2) only the rapid GDP growth affects people's subjective well-being (Bjørnskov et al. 2008), (3) there is a bidirectional connection between human subjective and material well-being and the happiest people start earning more by becoming economically motivated (Diener and Biswas-Diener 2002, and Dolan, Peasgood and White 2008), (4) increase in revenues has the buffering effect in relation to life mishaps (Ahuvia and Friedman 1998).

Nevertheless, most studies prove that a positive correlation between people's economic and subjective well-being exists: (1) country's GDP growth leads to positive changes in people's perception of happiness (Hagerty and Veenhoven 2003, Veenhoven and Hagerty 2006), (2) in particular, it is observed in terms of low-income countries (Dolan, Peasgood and White 2008), (3) however in highincome countries, there is a certain income threshold at which people's happiness level does not grow higher together with increasing income, while in low-income countries, this threshold is not observed (Layard 2005), (4) there is also a so-called income saturation point at which human happiness level does not go up any more, on the contrary people's satisfaction with life increases (Kahneman and Deaton 2010). In relation to other national macroeconomic indicators' impact on the improvement of subjective well-being, the following findings emerge: income inequality has a negative impact on people's subjective well-being (Morawetz 1977), it leads to negative changes in subjective well-being of people and is more often noted in transition countries, and positive changes in the non-transition ones 


\section{SHS Web of Conferences}

(Alesina, Di Tella and MacCulloch 2004, Sanfey and Teksoz 2008), inflation and unemployment also leave a negative effect on people's subjective well-being (Di Tella et al. 2001, Di Tella et al. 2003; Lelkes 2006, Lucas et al. 2004). Many scientists believe that the assets owned by people as well as their debts and liabilities have greater impact on people's subjective well-being (Sirgy 2012; Headey, Muffels, and Wooden 2008; Han and Hong 2011).

Consequently, taking into account the abovementioned information, it is possible to conclude that in the context of the three Baltic States, Latvia has the lowest value of the indicators of inhabitants' subjective satisfaction with life in the country, Lithuania is almost at the same level with Latvia, though in a slightly better situation, but in Estonia there has been a tendency of approaching average indicators of other European countries.

Therefore the author of the research thinks that hypothesis H1 that was put forward in the present article has been proved to be true, on basis of above mentioned and analysed data, we may consider that in comparison with Latvia's neighboring countries, the subjective well-being of Latvian inhabitants depends not only on the level of GDP per capita, but also on such macroeconomic indicators as the rate of unemployment and inequality of income.

Therefore, in this situation we may say that assets and debts are significant predictors of life satisfaction and consequently we may believe that hypothesis $\mathrm{H} 2$ was also proved: subjective well-being of Latvian inhabitants depends on their economic conditions, i.e. on financial assets and debt burden that they have.

\section{Conclusions}

At the end of the $20^{\text {th }}$ century, a new tendency in evaluation of the territory development appeared in the world, i.e. together with objective statistical, social and economic indicators researchers and scientists also started to apply indicators of inhabitants' subjective evaluation of life within a definite area and their attitude to processes happening in the area. People's general satisfaction with life within a particular area and their feeling of happiness are the most widely used subjective indicators. In addition to it, the corner stone for researchers remains the question "Is money the secret of happiness?" or as researchers say, "Will raising the income of all, increase the happiness of all?"; world's scientists and researchers, when trying to find an answer to the afore-mentioned question, obtain contrary results. In the present article, taking Latvia and its closest neighbouring Baltic Sea region countries as an example, the author has analysed the significance of economic factors and their influence on the low subjective well-being level of inhabitants of Latvia In the research, it has been clarified that Latvian inhabitants' subjective evaluation was not growing together with GDP in 2010-2011 like it happened in Lithuania and Estonia, but on the contrary - it decreased. Analysing other economic indicators in the context of Latvia and its closest neighbours in the Baltic Sea region, it is obvious that the subjective evaluation of Latvian inhabitants is influenced not only by the low GDP per capita, but also by high rate of unemployment and inequality of income, as well as low sum of personal net financial assets per capita and large amount of obligations, i.e. hard debt burden. In the article, the author marks the extraordinary significance of usage of subjective indicators when evaluating development of any area, since using such indicators together with social and economic indicators it is possible to gain credible results.

\section{References}

[1] Ahuvia, A.C., Friedman, D.C. (1998). Income, consumption, and subjective well-being: Toward a composite macromarketing model. Journal of Macromarketing, 18, p.153-168.

[2] Alesina, A., Di Tella, R., MacCulloch, R. (2004). Inequality and happiness: are Europeans and Americans different? Journal of Public Economics 88 (2004) 2009 - 2042. Online: http://www.economics.harvard.edu/faculty/alesina/files/Inequality\%20and\%20Happiness.pdf (access 28.10.2012.) 


\section{Int. Conf. SOCIETY. HEALTH. WELFARE.}

[3] Allianz Global Wealth Report (2012). Allianz SE, Economic Research \& Corporate Development. Online: https://www.allianz.com/media/economic_research/publications/specials/ en/GWR2012e.pdf (access 28.10.2012.)

[4] Bjørnskov, C., Gupta N. D., Pedersen, P. J. (2008). Analysing trends in subjective well-being in 15 European countries, 1973-2002. Journal of Happiness Studies, 9, p.317-330.

[5] Diener, E., Biswas-Diener, R. (2002). Will Money Increase Subjective Well-Being? A Literature Review and Guide to Needed Research. Social Indicators Research, 57, p.119-169.

[6] Di Tella, R., MacCulloch, R.J., Oswald, A.J. (2001). Preferences over Inflation and unemployment: Evidence from Surveys of Happiness. The American Economic Review, 91 (1), p.335-341. Online: http://www.people.hbs.edu/rditella/papers/AERHappyInflation.pdf (access 28.10.2012.)

[7] Di Tella, R., MacCulloch, R.J, Oswald, A.J (2003). The macroeconomics of happiness. The Review of Economics and Statistics, 85 (4), p.809-827. Online: http://www.econstor.eu/ dspace/bitstream/10419/39619/1/269376186.pdf (access 28.10.2012.)

[8] Dolan, P., Peasgood, T., White, M. (2008). Do we really know what makes us happy? A review of the economic literature on the factors associated with subjective well-being. Journal of Economic Psychology 29 (2008), p. 94-122.

[9] Easterlin, R.A. (1974). Does Economic Growth Improve the Human Lot? Some Empirical Evidence. P.A.David \& M.W.Reder (Eds.), Nations and Households in Economic Growth, Academic Press, New York, p. 89-125. Online: http://graphics8.nytimes.com/images/2008/ 04/16/business/Easterlin1974.pdf (access 28.10.2012.)

[10] Easterlin, R.A. (1995). Will raising the incomes of all increase the happiness of all? Journal of Economic Behavior and Organization 27, p.35-47.

[11] Eurobarometer (2007a). "Public Opinion in the European Union", Standard Eurobarometer 67, Spring 2007, TNS Opinion \& Social. Online: http://ec.europa.eu/public_opinion/archives/ eb/eb67/eb67_en.pdf (access 28.10.2012.)

[12] Eurobarometer (2007b). "Public Opinion in the European Union", Standard Eurobarometer 68, Autumn2007, TNS Opinion \& Social. Online: http://ec.europa.eu/public_opinion/ archives/eb/eb68/eb_68_en.pdf (access 28.10.2012.)

[13] Eurobarometer (2008a). "The European Union and its Citizens", Standard Eurobarometer 69, Spring 2008, TNS Opinion \& Social. Online: http://ec.europa.eu/public_opinion/ archives/eb/eb69/eb69_part2_en.pdf (access 28.10.2012.)

[14] Eurobarometer (2008b). "Public Opinion in the European Union", Standard Eurobarometer 70, Autumn2008, TNS Opinion \& Social. Online: http://ec.europa.eu/public_opinion/archives/ eb/eb70/eb70_full_en.pdf (access 28.10.2012.)

[15] Eurobarometer (2009a). "Social Climate", Special Eurobarometer 315 / Wave EB71.2 European Opinion Research Group. Online: http://ec.europa.eu/public_opinion/archives/ebs/ ebs_315_en.pdf (access 28.10.2012.).

[16] Eurobarometer (2009b). "Public Opinion in the European Union. National Report. Latvia”, Standard Eurobarometer 72, Autumn2009, TNS Opinion \& Social. Online: http://ec.europa.eu/public_opinion/archives/eb/eb72/eb72_lv_lv_nat.pdf (access 28.10.2012.)

[17] Eurobarometer (2010a). "Public Opinion in the European Union", Standard Eurobarometer 73. Table of Results, May 2010. Online: http://ec.europa.eu/public_opinion/archives/eb/eb73/ eb73_anx_full.pdf (access 28.10.2012.)

[18] Eurobarometer (2010b). "Public Opinion in the European Union", Standard Eurobarometer 74, Autumn2010, TNS Opinion \& Social. Online: http://ec.europa.eu/public_opinion/archives/ eb/eb74/eb74_publ_en.pdf (access 28.10.2012.)

[19] Eurobarometer (2011). "Social Climate", Special Eurobarometer 370 / Wave EB75.4 TNS opinion \& social. Online: http://ec.europa.eu/public_opinion/archives/ebs/ebs_370_en.pdf (access 28.10.2012.) 


\section{SHS Web of Conferences}

[20] Eurostat database. Online: http://epp.eurostat.ec.europa.eu/tgm/table.do?tab=table\&init $=1 \&$ plugin $=1 \&$ language $=$ en $\&$ pcode $=$ tec00114 (access 28.10 .2012 .)

[21] http://epp.eurostat.ec.europa.eu/tgm/table.do?tab=table\&init=1\&plugin=1\&language=en\&pcode $=$ tec00115 (access 28.10.2012.)

[22] http://appsso.eurostat.ec.europa.eu/nui/show.do?dataset=une_rt_q\&lang=en (access 28.10.2012.)

[23] http://epp.eurostat.ec.europa.eu/tgm/table.do?tab=table\&language $=$ en $\&$ pcode $=$ tec00118\& tableSelection $=1 \&$ footnotes $=$ yes $\&$ labeling=labels\&plugin $=1($ access 28.10 .2012$.

[24] http://epp.eurostat.ec.europa.eu/tgm/table.do?tab=table\&init=1\&language=en\&pcode $=$ tessi190\&plugin $=0$ (access 28.10.2012.)

[25] Hagerty, M., Veenhoven, R. (2003). Wealth and Happiness Revisited - Growing National Income Does Go With Greater Happiness. Social Indicators Research 64: p.1-27, 2003.

[26] Han, C.K., Hong, S.I. (2011). Assets and Life Satisfaction Patterns among Korean Older Adults: Latent Class Analysis. Social Indicators Research (2011) 110, p.225-240.

[27] Headey, B., Muffels, R., Wooden, M. (2008). Money Doesn't Buy Happiness... Or Does It? A Reconsideration Based on the Combined Effects of Wealth, Income and Consumption. IZA discussion papers Nr. 1218. Online: http://ftp.iza.org/dp1218.pdf (access 28.10.2012.)

[28] Human Development Report (2011) Sustainability and Equity: A Better Equity for All. United Nations Development Programme. Palgrave Macmillan Houndmills, Basingstoke, Hampshire RG21 6XS and 175 Fifth Avenue, New York, NY 10010.

[29] Kahneman D., Deaton A. (2010). High Income Improves Evaluation of Life but not Emotional Well-being. PNAS, Vol. 107, No. 38. Online: http://www.pnas.org/content/early/ 2010/08/27/1011492107 (access 28.10.2012.)

[30] Layard R. (2005). Happiness: Lessons From a New Science. United States of America: Penguin Books Ltd.

[31] Legatum Prosperity Index (2011). Online: http://www.prosperity.com/ (access 28.10.2012.)

[32] Lelkes, O. (2006). Tasting Freedom: Happiness, Religion and Economic Transition. Journal of Economic Behavior and Organization, 59(2), p.173-194.

[33] Lucas, R.E., Clark, A.E., Georgellis, Y., Diener, E. (2004). Unemployment alters the set point for life satisfaction. Psychological Science, 15, p.8-13.

[34] Morawetz, D. (1977). Income distribution and self-rated happiness: Some empirical evidence. The Economic Journal, 87, p.511-522.

[35] Rimgailaite, R. (2012). Igaunijas inflācija. Misija - meklējam vain̄̄go! Online: http://www. makroekonomika.lv/igaunijas-inflacija-misija-meklejam-vainigo (access 28.10.2012.)

[36] Rojas, M. (2011). Happiness, Income, and Beyond. Applied Research Quality Life (2011) 6: p.265-276.

[37] Sanfey, P., Teksoz, U. (2008). Life in transition: are people happier after a decade and a half? Paper Prepared for the 30th General Conference of The International Association for Research in Income and Wealth. Online: http://www.iariw.org/papers/2008/sanfey.pdf (access 28.10.2012.)

[38] Sirgy, M.J. (2012). Effects of Income and Wealth on Subjective QOL. The Psychology of Quality of Life: Hedonic Well-Being, Life Satisfaction, and Eudaimonia, Social Indicators Research Series 50, p.81-94.

[39] Veenhoven, R. (2011). Happiness in Nations. World Database of Happiness, Erasmus University Rotterdam, The Netherlands. Online: http://www1.eur.nl/fsw/happiness/index.html (access 28.10.2012.)

[40] Veenhoven, R., Hagerty, M. (2006). Rising Happiness in Nations 1946-2001: a Reply to Easterlin. Social Indicators Research 79, p.421-436.

[41] World Database of Happiness. Online: http://www1.eur.nl/fsw/happiness/ (access 28.10.2012.) 